8. Процедура бізнес-планування та iii вплив на розвиток малого бізнесу / О.Л. Черевко, А.В. Іванісова, Т.Л. Гарькава // Культура народов Причерноморья. 2013. — № 257. — С. 154-158. - Бібліогр.: 13 назв. - укр.
9. Саммер
А., Дункан
$\Gamma$.

Маркетинг: Пятая волна. E-commerce. М.: 1999. - 152 c.

10. Іванілов О.С. Економіка підприємства [Текст] : підручник / О.С. Іванілов. - К. : Центр учбової літератури, $2009-728 \mathrm{c}$.

DOI 10.18664/338.47:338.45.v0i64.149972

УДК 658(477)

\title{
СТРАТЕГІЧНІ НАПРЯМКИ ПІДВИЩЕННЯ ЕФЕКТИВНОСТІ ДІЯЛЬНОСТІ ПІДПРИЕМСТВ У СУЧАСНИХ УМОВАХ ГОСПОДАРЮВАННЯ
}

\author{
Уткіна Ю.М., к.е.н., доцент, \\ Тупікова О.Г., магістр (УкрДУЗТ)
}

Актуальність дослідження стратегічних напрямків підвищення ефективності діяльності промислового підприємства визначається необхідністю розробки, адекватного иілям $i$ специфіці ринкових відносин методологічного й методичного інструментарію, щз забезпечує формування й реалізацію конкурентоспроможних управлінських стратегій підвищення ефективності діяльності промислових підприємств. Якщо керівництво підприємства зацікавлене у тому, щзоб домагатися кращих результатів, воно мусить аналізувати інформацію про стан зовнішнього $i$ внутрішнього середовища.

Ключові слова: стратегічне управління, підвщщення ефективності, фактори підвищення ефективності, конкурентоспроможні управлінські стратехї, підприємство.

\section{СТРАТЕГИЧЕСКИЕ НАПРАВЛЕНИЯ ПОВЫШЕНИЯ ЭФФЕКТИВНОСТИ ДЕЯТЕЛЬНОСТИ ПРЕДПРИЯТИЙ В СОВРЕМЕННЫХ УСЛОВИЯХ ХОЗЯЙСТВОВАНИЯ}

\author{
Уткина Ю.М., к.е.н., доцент, \\ Тупикова О.Г., магистр (УкрГУЖТ)
}

\begin{abstract}
Актуальность исследования стратегических направлений повышения эффективности деятельности промышленного предприятия определяется необходимостью разработки адекватного иелям и специифике рыночных отнотений методологического и методического инструментария, обеспечивающего формирование u реализацию конкурентоспособных управленческих стратегий повышения эффективности деятельности промышленных предприятий. Если руководство предприятия заинтересовано в том, чтобы добиваться лучших результатов, оно должно анализировать информащию о состоянии внешней и внутренней среды.
\end{abstract}


Ключевые слова: стратегическое управление, повышение эффективности, факторы повышения эффективности, конкурентоспособные управленческие стратегии, предприятие.

\title{
STRATEGIC DIRECTIONS OF INCREASE OF EFFICIENCY OF ACTIVITY OF ENTERPRISES IN MODERN CONDITIONS OF MANAGING
}

\author{
Utkina Yu.M., Ph.D. in Economics, associate Professor, \\ Tupikova O.G., magister (USURT)
}

The relevance of the study of strategic directions to improve the efficiency of industrial enterprises is determined by the need to develop adequate goals and specifics of market relations methodological and methodological tools to ensure the formation and implementation of competitive management strategies to improve the efficiency of industrial enterprises. On the basis of the study, the author found that the search for strategic directions to improve the efficiency of the enterprise is advisable to carry out in accordance with the model of strategic management, which justifies the implementation of activities to achieve the mission of the enterprise through the establishment of the strategic goal and its decomposition in the form of a tree of tactical and current goals, which occurs under the control of the selected centers of responsibility at the level of the management apparatus and at the level of structural units, which takes place under constant monitoring of the degree of implementation of tactical and current goals in order to adjust them if necessary, the degree of achievement of the established strategic goal by means of feedback.

If the company's management is interested in achieving better results, it should analyze information about the state of the external and internal environment. Then it will be clear which of the existing factors need to be used for the benefit of future strategic development. These include: the minimum involvement of resources. improving the efficiency of staff by optimizing the structure, training and development, search for more competent personnel, changes in the motivational system; strengthening of social and psychological factors; application of the results of scientific and technological progress; use of diversification, cooperation and other strategies that allow the use of available resources in various projects; attraction of investment capital and other third-party financing mechanisms.

Key words: strategic management, efficiency improvement, efficiency improvement factors, competitive management strategies, enterprise.

Постановка проблеми та ї̈ зв'язки з науковими чи практичними завданнями. Сучасний стан української економіки характеризується сукупністю особливих рис, що визначають потреби в розробці нових теоретичних підходів та практичних заходів щодо формування стратегічного управління виробничогосподарської діяльності вітчизняними підприємствами. У результаті стрімких ринкових перетворень, менталітет керівників та уся внутрішня організація промислових підприємств виявились не підготовленими до виконання ними нових виробничо-економічних функцій. Не маючи досвіду та інструментів стратегічного управління, які б дозволили ураховувати наростаючу конкуренцію, нестабільність i непередбачуваність зовнішнього оточення, їм складно забезпечити ефективність господарювання та власну конкурентоспроможність.

Будь-яке підприємство рано чи пізно стикається з проблемою підвищення ефективності виробництва. I не завжди йдеться про економічну складову. Яким

Вісник економіки транспорту і промисловості № 64, 2018 
методам віддати перевагу при організації подібної роботи, вирішує керівництво підприємства. Грунтуючись на знаннях внутрішнього та зовнішнього середовища, особливості процесів виробництва, можна розробляти план, який приведе до досягнення поставленої мети.

Ефективність підприємства $\epsilon$ економічною категорією. Під цим поняттям розуміють результативність компанії, яка може виражатися в: зростання темпів виробництва; зниження витрат, податкового навантаження; зменшення кількості викидів в навколишнє середовище; підвищення продуктивності праці і т.д.

Актуальність

стратегічних напрямків підвищення ефективності діяльності промислового підприємства визначається необхідністю розробки, адекватного цілям і специфіці ринкових відносин методологічного й методичного інструментарію, що забезпечує формування й реалізацію конкурентоспроможних управлінських стратегій підвищення ефективності діяльності промислових підприємств.

Аналіз останніх досліджень $i$ публікацій. Проблематика стратегічного управління взагалі $\epsilon$ доволі добре дослідженим питання. Достатньо глибоко дана тематика розглядається у роботах $\mathrm{H}$. Аванесової, О. Марченко [1], В. Василенко, Т. Ткаченко [6], І. Отенко [7], Л. Романюк [8], О. Сумець, М. Бондаренко [9], О. Кірдіної [10] та ін. Окремі аспекти сутності стратегічного управління в аспекті забезпечення ефективності функціонування підприємства розглянуто у працях В. Диканя, О. Полякової, В. Зубенко, О. Маковоз, І. Токмакової, О. Шраменко, С. Панченко, В. Маслової, І. Воловельської [2-4].

Виділення невирішених частин загальної проблеми. Разом з тим, на нашу думку, недостатньо опрацьованим залишаються питання щодо визначення напрямків підвищення ефективності діяльності підприємства в стратегічному аспекті в сучасних економічних реаліях.

\section{Формування цілей статmі}

(постановка завдання). Саме тому метою статті є визначення стратегічних напрямків підвищення ефективності діяльності підприємства в сучасних умовах господарювання.

Виклад основного матеріалу дослідження. Стратегічне управління - це процес розробки стратегій і управління організацією для успішної іiі реалізації. Організації i керівники, які мислять стратегічно, дивляться вперед і визначають напрямок, в якому вони бажають рухатися. Не дивлячись на свою впевненість, що бізнес, як і керівники, повинен працювати добре і прямо зараз, щоб добре розвиватися в майбутньому, їх цікавить більш широкий спектр проблем, 3 якими вони зустрічаються, і загальний напрямок, в якому вони повинні рухатися, щоб вирішувати ці проблеми [7]. Воно здійснюється в контексті місії організації, а його фундаментальна задача полягає в забезпеченні взаємозв'язку місії 3 основними цілями організації в умовах змінного економічного середовища. Саме тому стратегічне управління стосується й цілей, і засобів (рис. 1).

На практиці стратегічне управління - це симбіоз інтуїції і мистецтва вищого керівництва вести бізнес до стратегічних цілей; високий професіоналізм і творчість службовців, що забезпечують зв'язок підприємства iз середовищем, активне залучення всіх працівників до реалізації завдань підприємства, до пошуку найкращих шляхів досягнення його цілей [10].

На основі проведеного дослідження автором встановлено, що пошук стратегічних напрямків підвищення ефективності діяльності підприємства доцільно проводити у відповідності до моделі наступної стратегічного управління (рис. 2). 


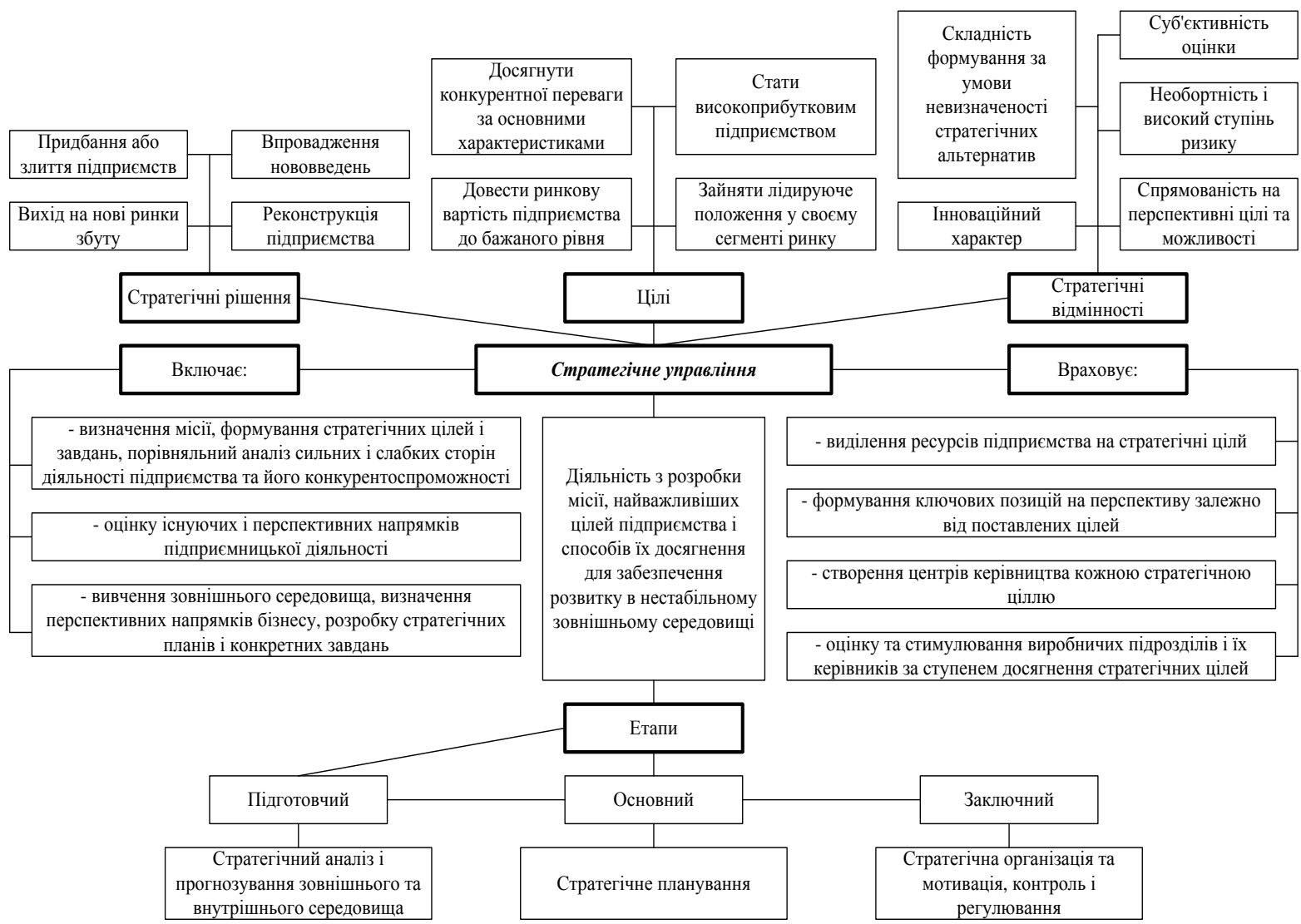

Рис. 1. Стратегічне управління як процес вибору та реалізаџії иүілей та стратегії підприсмства $[1 ; 2]$

Вона обгрунтовує реалізацію діяльності 3 досягнення сформованої місії підприємства через встановлення стратегічної цілі та ії декомпозиції у вигляді дерева тактичних і поточних цілей, що відбувається під контролем виокремлених центрів відповідальності як на рівні управлінського апарату, так і на рівні структурних підрозділів, яка відбувається під постійним моніторингом ступеня виконання тактичних і поточних цілей 3 метою їх корегування у разі необхідності ступеня досягнення встановленої стратегічної цілі засобами зворотнього зв'язку. Особливість даної моделі полягає у формуванні місії підприємства не тільки на основні результатів аналізу зовнішнього середовища, але й 3 урахуванням внутрішніх можливостей підприємства, що дозволяє досягти максимально ефективного процесу реалізації місії підприємства.

У більшості випадків, прагнучі підвищити ефективність організації, керівництво розраховує отримати певний фінансовий результат. Але це не завжди відображає стратегічне майбутне виробництва. Тому вважається, що правильніше домагатися темпів зростання [8]. Можна говорити, що вдалося домогтися економічної ефективності виробництва, якщо:

- отриманий фінансовий результат вище, ніж у конкурентів;

- в організації виділяється достатньо ресурсів для проведення виробничих або управлінських змін;

- темпи зростання фінансових показників будуть вище в найближчій перспективі, ніж у конкурентів.

Такий підхід постійно мотивує на пошук рішень, які підвищують конкурентоспроможність виробництва. Це $\epsilon$ важливим, для того щоб проводити роботи, спрямовані на стратегічний розвиток [6]. 


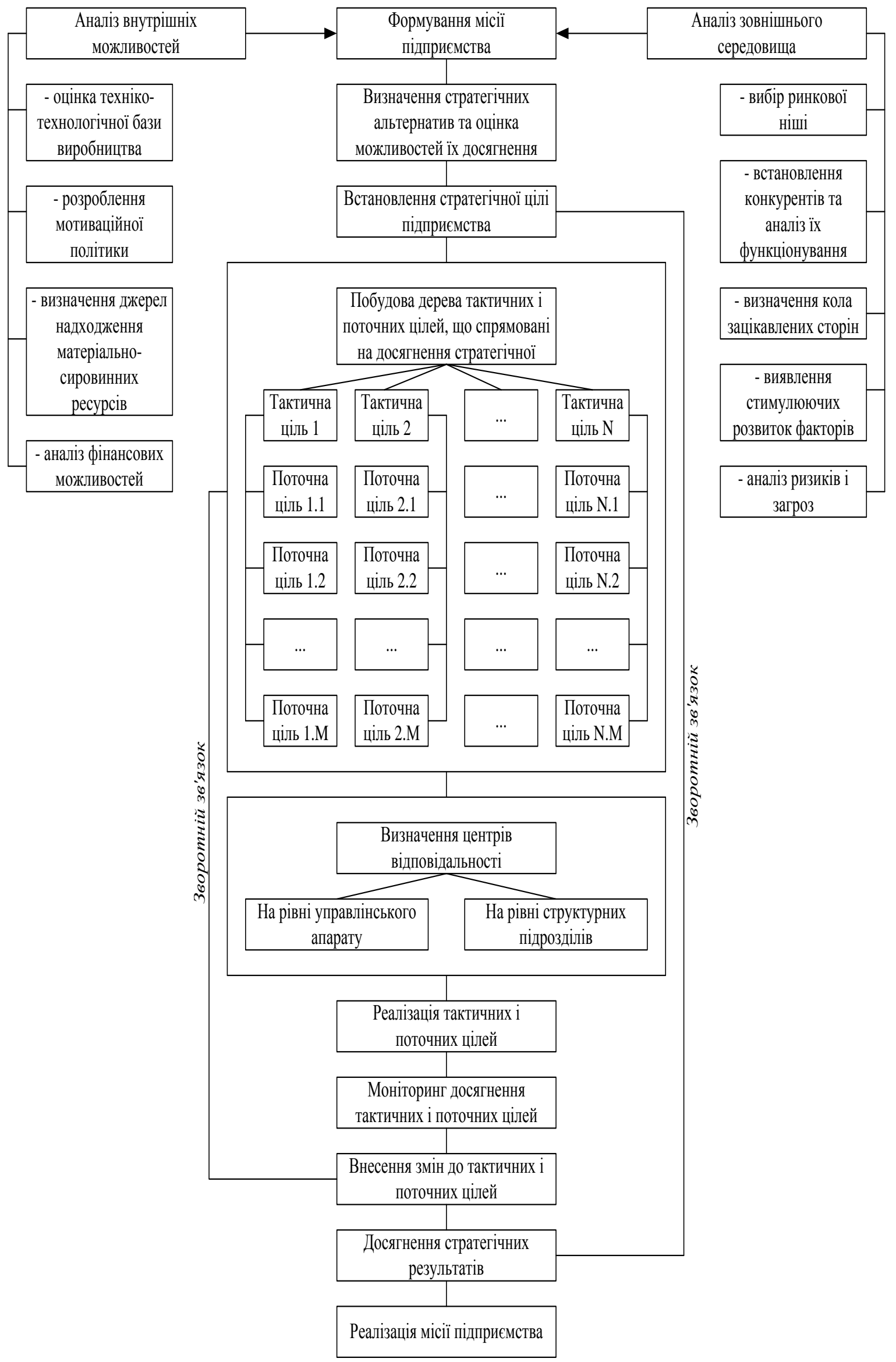

Рис. 2. Модель стратегічного управління підприємством

Вісник економіки транспорту і промисловості № 64, 2018 
Має значення i те, щоб кожний структурний підрозділ організації був стурбоване пошуком шляхів підвищення його економічної ефективності. Адже якщо слабо працює одне 3 них, організації не вдасться підвищити свою результативність в цілому.

Рівень економічної та соціальної ефективності діяльності промислового підприємства у стратегічній перспективі, на нашу думку, залежить від багатьох чинників. Тому для практичного розв'язання завдань стратегічного управління ефективністю важливого значення набуває класифікація чинників іiі зростання за певними ознаками. Класифікацію чинників зростання ефективності (продуктивності) виробничоекономічних та інших систем діяльності доцільно здійснювати за трьома ознаками: видами витрат i ресурсів (джерелами підвищення); напрямами розвитку та вдосконалення виробництва (діяльності); місцем реалізації в системі управління виробництвом (діяльністю) [3].

Перший 3 напрямків підвищення ефективності діяльності підприємства ресурсний - відображає першочергову необхідність аналізу ефективності використання наявної матеріальної бази виробництва та живої праці. При цьому слід враховувати рівень завантаження обладнання в часі, структуру собівартості продукції, що виготовляється, з точки зору співвідношення в ній часток амортизації, матеріальних витрат, витрат на оплату праці. Зазначені показники слід розглянути в динаміці, а також по можливості порівняти 3 показниками найближчих конкурентів. Для оборотних фондів найважливішим показником $є$ швидкість їх обороту, отже, слід проаналізувати чинники ऑï збільшення, зокрема такі: зменшення обсягів незавершеного виробництва; удосконалення системи матеріально-технічного забезпечення 3 метою оптимізації виробничих запасів; прискорення реалізації готової продукції (активізація маркетингової діяльності); зменшення

обсягів

дебіторської

заборгованості.

Крім того, слід звернути увагу і на інші напрямки раціоналізації використання матеріальних ресурсів: проаналізувати основні причини втрат та нераціонального використання ресурсів; забезпечити обгрунтоване нормування витрат матеріалів; організувати використання вторинних ресурсів; створити систему заохочення за економію сировини, енергії та матеріалів й відпрацювати їі дійовість; акцентувати увагу на використанні сучасних високотехнологічних матеріалів [5].

Що стосується аналізу ефективності використання трудового потенціалу підприємства, то тут слід зосередити увагу на таких аспектах: внутрішньозмінні втрати робочого часу; втрати робочого часу внаслідок плинності кадрів; рівень використання засобів механізації, автоматизації праці та комп'ютерної техніки; аналіз системи стимулювання працюючих; визначення професійнокваліфікаційної структури працюючих.

$$
\text { у межах другого, тобто }
$$
організаційного, напрямку здійснюється пошук можливостей підвищення ефективності тих процесів, що відбуваються на підприємстві. При цьому насамперед увага звертається на ефективність управління.

Важливою складовою ефективності підприємства, а отже, і значним резервом іiі підвищення, $\epsilon$ організація виробничого процесу. У конкретних умовах підприємства слід проаналізувати всі аспекти, що визначають ефективність організації робіт, від рівня робочого місця окремого робітника чи спеціаліста до рівня підприємства в цілому. Для виробничих підприємств, ураховуючи, звичайно, специфіку їх діяльності, особливу увагу треба звертати на можливості застосування більш ефективних типів виробництва (масового, великосерійного) [4].

I, нарешті, останнім (але не за важливістю) напрямком пошуку 
можливостей підвищення ефективності $€$ технологічний. Вирішення проблеми технологічного відставання особливо актуальне для українських підприємств. Причому проблема ця є комплексною і має, принаймні, два компоненти: матеріальний та нематеріальний. Перший 3 них - це удосконалення технічної бази, а другий організаційно-правові проблеми. На думку багатьох економістів, подолання технічного i технологічного відставання потребує не просто переходу на сучасні технології, а впровадження комплексу відносин, що називається корпоративною культурою. Така культура має запозичуватись, звичайно, у найпередовіших компаній 3 тривалим досвідом роботи в ринковому середовищі.

Шляхи підвищення ефективності діяльності підприємства дуже різноманітні. Основні способи, що дозволяють збільшити прибуток організації, зводяться до наступного:

- зниження витрат, досягти якого можна шляхом скорочення цінових умов по закупівлях, оптимізації виробництва, скорочення персоналу або рівня оплати праці;

- модернізація процесів або всього виробництва, яка дозволяє добитися підвищення продуктивності праці, зниження обсягів перероблюваної сировини, відходів, автоматизації більшості операцій;

- зміни в організаційній системі, здатні порушувати структуру управління, принципи обслуговування клієнтів, комунікації і т. д.;

- посилення маркетингових комунікацій, коли завданням $\epsilon$ максимальне зростання обсягів збуту товару, зміна ставлення до організації, знаходження нових можливостей для виробництва.

Висновки даного дослідження $i$ перспективи подальших робіт у цьому напрямку. Таким чином, в стратегічному аспекті намагання виділити в оцінці ефективності підприємства та в пошуку шляхів підвищення останньої окремі структурні компоненти зумовлено бажанням спростити розуміння зазначених проблем. Проте зрозуміло, що насправді ці проблеми комплексні, отже, для їх вирішення слід застосовувати комплексний, системний підхід, ретельно досліджуючи всі підрозділи, служби підприємства та ті процеси, які в них відбуваються. Тільки на основі системного аналізу можна отримати справді адекватну оцінку стану справ на підприємстві та розробити ефективні заходи щодо його поліпшення.

Якщо керівництво підприємства зацікавлене у тому, щоб домагатися кращих результатів, воно мусить аналізувати інформацію про стан зовнішнього і внутрішнього середовища. Тоді буде зрозуміло, які 3 існуючих факторів необхідно використовувати на благо майбутнього стратегічного розвитку. До них можна віднести:

- мінімальне залучення ресурсів. Чим менше використовуються технології, обладнання, персонал при збереженні обсягів випуску продукції, тим ефективніше організація;

- підвищення ефективності персоналу за рахунок оптимізації структури, підвищення кваліфікації та навчання, пошуку більш компетентних кадрів, зміни мотиваційної системи;

посилення соціальнопсихологічних факторів. Використання інструментів децентралізації в управлінні може стати хорошим поштовхом для розвитку;

- застосування результатів науковотехнічного прогресу. Ігнорування сучасних технологій або відмовки від їх впровадження у зв'язку 3 необхідністю інвестицій призводять до зниження конкурентоспроможності і можливої ліквідації згодом. Побоюючись несприятливої економічної ситуації в поточному періоді, компанії часто закривають собі дорогу для розвитку в майбутньому; 
- використання диверсифікації, кооперації та інших стратегій, що дозволяють використовувати наявні ресурси в різних проектах;

- залучення інвестиційного капіталу та інших механізмів стороннього фінансування. Навіть приватизація здатна відкрити шляхи підвищення ефективності діяльності підприємства.

Всі ці фактори призводять не тільки до зростання економічної, але i управлінської ефективності діяльності промислового підприємства в стратегічному аспекті.

\section{ПЕРЕЛІК ВИКОРИСТАНИХ ДЖЕРЕЛ}

1. Аванесова, Н.Е. Стратегічне управління підприємством та сучасним містом [Текст]: монографія / H.Е. Аванесова, О.В. Марченко. - Х.: Щедра садиба, 2015. - 195 с.

2. Дикань, В.Л. Стратегічне управління [Текст]: навч. посіб./ В.Л. Дикань, В.О. Зубенко, О.В. Маковоз, I.В. Токмакова, О.В. Шраменко - К.: «Центр учбової літератури», 2013. - 272 с.

3.

Панченко,

C.B.

Підприємництво [Текст]: підручник /

С.В. Панченко, В.Л. Дикань, О.В Шраменко, О.М. Полякова, Ю.М. Уткіна. Х.: УкрДУЗТ, 2016. - Ч.1. Теоретичні основи організації підприємницької діяльності. -241 с.

4. Панченко,

C.B Підприємництво [Текст]: підручник / С.В. Панченко, В.Л. Дикань, О.В. Шраменко, О.М. Полякова, Ю.М. Уткіна. -
Х.: УкрДУЗТ, 2016. - Ч.2. Реалізація підприємницької діяльності у сучасних ринкових умовах. $-241 \mathrm{c.}$

5. Панченко, С.В. Управління бізнесом [Текст]: підручник / C.В. Панченко, В.Л. Дикань, І.В. Воловельська та ін.; за заг. ред. В.Л. Диканя. - Харків: УкрДУЗТ, 2017. - 288 с.

6. Василенко, В.О. Стратегічне управління підприємством [Текст]: навч. посіб. / В.О. Василенко, Т.І. Ткаченко. - 2ге вид. випр. і доп. - К.: Центр навчальної літератури, 2014. - 400 с.

7. Отенко, И.П. Стратегическое управление потенциалом предприятия [Текст]: монографія / И.П. Отенко. - Х.: ХНЭУ, 2006. - $256 \mathrm{c}$.

8. Романюк, Л.М. Сучасні тенденції стратегічного управління підприємством [Електронний ресурс] / Л.М. Романюк. Режим доступу: http://www.library.if.ua/book/60/4194.html

9. Сумець, О.М. Стратегічний менеджмент [Текст]: навч. посіб. / O.М. Сумець, М.I. Бондаренко. - К.: «ХайТек Прес», 2010. - 240 с.

10. Кірдіна, О.Г. Ефективне промислове виробництво як основа розвитку економіки України [Текст] / О.Г. Кірдіна // Вісник економіки транспорту та промисловості: зб. наук. - практ. статей. Харків: УкрДАЗТ, 2012. - Вип. 40.- С. 4042.

11. Lambert, D.M. Establishing Customer Service Strategies Within the Marketing Mix [Text] / D.M. Lambert, T.C. Harrington // Journal of Business Logistics. 1989. - №2. - P. 32-35.

DOI 10.18664/338.47:338.45.v0i64.149973 